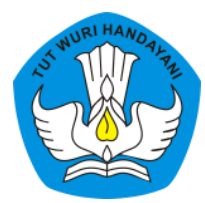

Page: 641-654

\title{
Penggunaan Media "Alga Maji" Untuk Meningkatkan Hasil Belajar PAI Materi Haji Dan Umrah Kelas IX A SMP Negeri 4 Gantung
}

\author{
Heriyanto \\ Sekolah Menengah Pertama Negeri 4 Gantung, Belitung Timur, Bangka Belitung \\ Contributor Email: heri.yanto209@yahoo.com
}

Article Url: http://ojsdikdas.kemdikbud.go.id/index.php/didaktika/article/view/144

\begin{abstract}
The aim of this learning innovation is to realize 21st century learning and the era of the industrial revolution 4.0 namely critical thinking, collaborating, communicating effectively, and creativity in learning and shaping the character of learners, as well as increasing understanding and learning outcomes in Hajj and Umrah material for class IX A SMP Negeri 4 Gantung, East Belitung Regency, Bangka Belitung Islands. Based on the results of a questionnaire from students and direct observation conducted by the teacher, as well as the results of evaluations that have been carried out, the use of the media "Alga Maji" and Hajj Videos on Hajj material in class IX A obtained results, namely learning by using the tools "Alga Maji" and The Hajj video can create 21st century learning and the 4.0 revolution era, namely critical thinking and collaboration in solving problems, in describing and explaining the order of the implementation of the pilgrimage. In addition, the use of the media "Alga Maji" and Video Hajj is also able to shape the character of the brave and confident students appear in front of the class when presenting the implementation of the pilgrimage and be responsible and trustful when getting assignments. The use of the media of the Hajj manasik props "Alga Maji" and the Hajj Video in the teaching of Islamic religious education (PAI) is proven to be able to improve students' understanding and learning outcomes with 100\% mastery learning. This is supported by a fun and interesting learning process that motivates students and makes it easy to master the material by using the media "Alga Maji" and Hajj Video.
\end{abstract}

Keywords: Alga Maji Media; Hajj Video; Learn PAI; Hajj 


\begin{abstract}
Abstrak
Tujuan dari inovasi pembelajaran ini adalah untuk mewujudkan pembelajaran abad 21 dan era revolusi industri 4.0, yaitu berpikir kritis, kolaboratif, berkomunikasi efektif dan kreatif dalam pembelajaran dan pembentukan karakter peserta didik, serta peningkatan pemahaman dan hasil belajar pada materi Haji dan Umrah kelas IX A SMP Negeri 4 Gantung, Kabupaten Belitung Timur, Bangka Belitung. Berdasarkan hasil angket dari peserta didik dan observasi langsung yang dilakukan oleh guru, serta hasil evaluasi yang telah dilaksanakan, penggunaan media "Alga Maji" dan Video Haji pada materi haji pada kelas IX A diperoleh hasil, yaitu pembelajaran dengan menggunakan alat peraga "Alga Maji" dan Video Haji dapat menciptakan pembelajaran abad 21 dan era revolusi 4.0 yaitu berpikir kritis dan kolaboratif dalam menyelesaikan masalah, dalam menjabarkan dan menjelaskan tata urutan pelaksanaan ibadah haji. Selain itu, penggunaan media "Alga Maji" dan Video Haji juga mampu membentuk karakter berani dan percaya diri peserta didik tampil di depan kelas ketika mempresentasikan pelaksanaan ibadah haji serta bertanggung jawab dan amanah ketika mendapatkan tugas. Penggunaan media alat peraga manasik haji "Alga Maji"dan Video Haji dalam pembelajaran pendidikan agama Islam (PAI) terbukti dapat meningkatkan pemahaman dan hasil belajar peserta didik dengan ketuntasan belajar $100 \%$. Hal ini didukung proses pembelajaran yang menyenangkan dan menarik serta memotivasi peserta didik serta memudahkan untuk menguasai materi dengan menggunakan media "Alga Maji"dan Video Haji.
\end{abstract}

Keywords: Media Alga Maji; Video Haji; Belajar PAI; Haji

\title{
A. Pendahuluan
}

Kegiatan belajar di kelas menuntut seorang guru mengambil peran penting sebagai fasilitator, mediator, motivator, dalam menciptakan kondisi belajar yang berkualitas. Guru semestinya memiliki kompetensi dalam menciptakan kegiatan belajar yang berkualitas dan memiliki kompetensi menciptakan kondisi pembelajaran yang menjadikan peserta didik melakukan aktivitas belajar (Sudjana, 2009:63). Belajar tidak sekadar mengubah peserta didik dari tidak bisa menjadi bisa melalui pengalaman langsung yang mereka maknai dalam proses pembelajaran. Belajar bukan hanya proses yang bersifat satu arah, guru mentransfer dan memasukan pengetahuan secara langsung pada peserta didik. Munculnya motivasi belajar dari dalam diri siswa dipengaruhi oleh banyak faktor, motivasi yang berasal dari dalam diri dan luar diri seseorang (Daryanto, 2012:23). 


\section{Heriyanto}

Ketika hal itu terwujud, guru telah berhasil membangun sebuah kondisi kelas perserta didik menjadi mencintai pembelajaran (Dahar, 2011:45). Namun, melihat kenyataan saat ini di kelas IX A SMP Negeri 4 Gantung pembelajaran PAI materi haji dan umrah, suasana kelas terkadang menjadi "penjara" bagi siswa dan banyak siswa yang tidak fokus dengan pelajaran yang telah diberikan guru selalu monoton dengan metode ceramah. Mereka seperti terkurung secara fisik dan psikis, sehingga yang terjadi mereka hanya menunggu waktu jam istirahat dan jam pulang sekolah. Dengan kondisi seperti ini, kegiatan belajar mengajar menjadi suatu beban yang sangat berat bagi mereka (Arsyad, 2007:61). Hal ini disebabkan karena guru di dalam kelas tidak mampu menciptakan kondisi yang menyenangkan bagi peserta didik. Menurut Djamarah (2010:12) dunia anak sekolah setingkat SMP adalah dunia bermain, mengapa tidak di dalam kelas guru mendesain pembelajaran yang menyenangkan, sehingga peserta didik akan menikmati setiap detik dari proses pembelajaran yang disajikan guru.

Dengan keadaan demikian, penulis mencoba untuk mengubah metode dan media pembelajaran PAI di kelas IX A SMP Negeri 4 Gantung dengan membuat suatu inovasi berupa media "Alga Maji" dan menampilkan media Video ritual Haji pada Materi Haji dan Umrah. "Alga Maji" adalah singkatan Alat Peraga Manasik Haji yang berupa tampilan minatur tempat pelaksanaan dan ritual haji. Berdasarkan observasi yang dilakukan terhadap metode pembelajaran materi haji di kelas XI A SMP Negeri 4 Gantung Belitung Timur, diperoleh hasil bahwa guru memberikan pembelajaran di kelas menggunakan metode ceramah yang disertai alat bantu berupa buku panduan yang diberikan oleh Kementerian Agama Republik Indonesia tanpa dilengkapi dengan media pembelajaran lain kurang dari KKM.

Selain dilakukan observasi, dilakukan pula wawancara terhadap siswa kelas IX A dan diperoleh hasil bahwa kendala-kendala yang muncul ketika memberikan materi haji dan umrah di kelas IX A SMP Negeri 4 Gantung diantaranya tidak ada media atau alat peraga yang 
dapat memberikan gambaran tata cara pelaksanaan ibadah Haji dan Umrah kepada kepada siswa kelas IX A SMP Negeri 4 Gantung di kelas. Untuk mengatasi permasalahan tersebut, penulis berusaha untuk membuat sebuah inovasi, yaitu membuat media alat peraga manasik haji (Alga Maji) dan menampilkan video ritual haji di layar proyektor. Inovasi ini tentunya diharapkan mampu mewujudkan pembelajaran abad 21 dan era revolusi industri 4.0, membentuk karakter peserta didik dan meningkatkan proses serta hasil belajar peserta didik.

Rumusan masalah dari penelitian ini yaitu (1) Bagaimanakah media "Alga Maji" dalam mewujudkan pembelajaran abad 21 dan era revolusi industri 4.0? (2). Bagaimanakah peningkatan hasil belajar peserta didik pada materi haji dan umrah setelah dilakukan pembelajaran dengan menggunakan media "Alga Maji”?

Tujuan penelitian ini adalah (1) untuk mewujudkan pembelajaran abad 21 dan era revolusi industri 4.0. dan (2) untuk meningkatkan hasil belajar PAI peserta didik pada materi haji dan umrah.

\section{B. Metode}

Penelitian ini merupakan penelitian pengembangan. Dalam penelitian ini, penulis menggunakan pendekatan kuantitatif dengan metode kolaborasi antara metode tanya jawab dan diskusi serta mempresentasikan hasil pengamatan dan penilaian terhadap kegiatan manasik haji di Kelas IX A SMP Negeri 4 Gantung yang dilakukan kelompok temannya melalui tayangan video pembelajaran dan alat peraga manasik haji (Alga Maji). Metode yang digunakan adalah presentasi dengan cara menjelaskan tata cara pelaksanaan dan urutan pelaksanaan ritual haji, menjawab pertanyaan dan berdiskusi dalam kelompok di bantu dengan media IT. Diharapkan dengan pengaplikasian metode dan pemanfaatan media tersebut akan meningkatkan proses dan hasil belajar peserta didik. Adapun langkah-langkah teknis metodologis dalam merancang pembuatan dan pelaksanaan media pembelajaran dimaksud, adalah sebagaimana tampak dalam gambar berikut. 


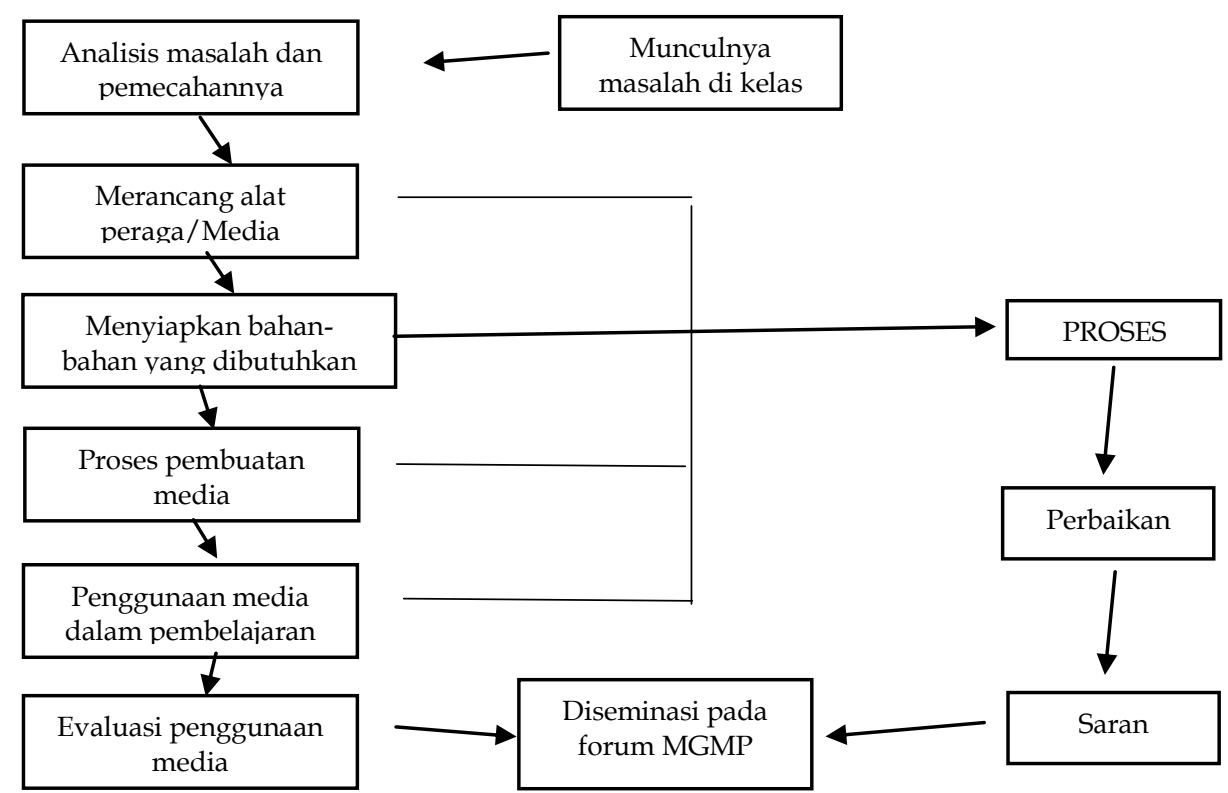

Gambar 1: Alir Metode Pembuatan Media Pembelajaran

\section{Hasil dan Pembahasan}

Berdasarkan uraian yang telah dikemukakan diuraikan sebelumnya, pada kesimpulan bahwa pembelajaran materi haji dan umrah akan semakin bermakna bila menggunakan alat peraga sebagai media pembelajaran, penulis kemudian merancang media pembelajaran yang dapat mensimulasikan kegiatan ibadah haji dan umrah serta berbentukan tayangan video ritual haji, bukan sekadar mengambarkan letak kakbah, Padang Arafah dan tempat lainnya saat ritual ibadah haji dan umrah.

Media pembelajaran yang kemudian diberi nama "Alga Maji" tersebut diyakini lebih baik, efektif dan praktis untuk digunakan oleh sekolah manapun dalam kegiatan pembelajaran pendidikan agama Islam materi haji dan umrah. Keyakinan penulis didasari pada beberapa inovasi pembelajaran lain yang dikembangkan sebelumnya yang telah membawa dampak positif pada peningkatan hasil belajar siswa. Padahal beberapa inovasi tersebut lebih sederhana dan belum mampu mendeskripsikan 
proses ritual ibadah haji dan umrah. Adapun bentuk karya inovasi yang dihasilkan dapat dilihat pada gambar di bawah ini.

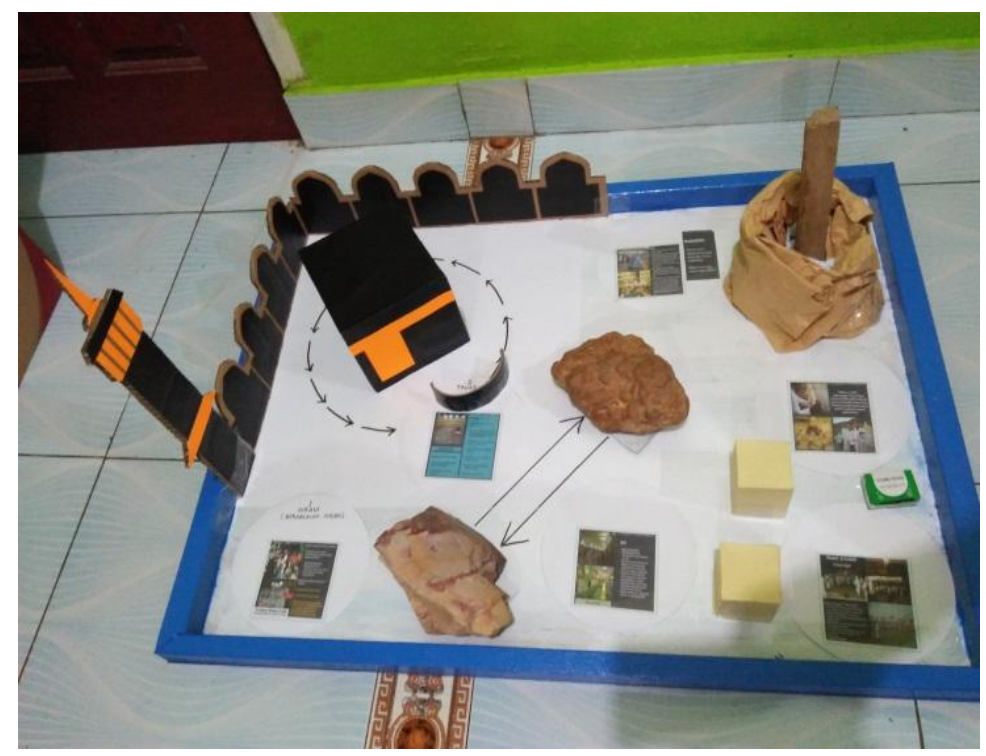

Gambar 2: Rancangan Media Alat Peraga Manasik Haji

Perancangan media "Alga Maji" membutuhkan bahan-bahan sederhana dan mudah didapat di lingkungan sekitar. Selain itu, proses pembuatannya tidak membutuhkan waktu panjang dan rumit.

Alat peraga manasik haji (Alga Maji) merupakan sebuah media sederhana yang berupa tampilan maket kakbah, bukit safa dan marwah, mina dan padang arafah yang dirancang secara berurutan untuk membangun pembelajaran yang berkualitas. Dalam pembelajaran ini mengangkat pendekatan kontruktivistik, peserta didik membangun pengetahuan berdasarkan pengalaman yang dirasakan secara langsung dalam pembelajaran membentuk karakter peserta didik. Langkah awal yang dilakukan pada tahapan pembuatan, yaitu menginventarisasi alat dan bahan-bahan yang akan digunakan pada saat melakukan rancang bagun alga maji. Alat yang dibutuhkan pada umumnya mudah diperoleh di lingkungan sekitar dan mudah digunakan. Demikian pula, bahan-bahan yang digunakan, hampir seluruhnya terdapat di lingkungan sekitar. Sejumlah alat dan bahan yang digunakan tersebut disajikan pada dua tabel berikut. 
Tabel 1: Alat yang Digunakan untuk Membuat "Alga Maji"

\begin{tabular}{|c|l|l|}
\hline No & \multicolumn{1}{|c|}{ Alat } & \multicolumn{1}{c|}{ Kegunaan } \\
\hline 1 & Gergaji & Pemotong teriplek dan papan \\
\hline 2 & Mesin Planer Serut Kayu & Untuk merapikan dan memuluskan permukaan papan dan kayu \\
\hline 3 & Pisau Cutter & Pemotong plastik bening \\
\hline 4 & Gunting & Pemotong kertas \\
\hline 5 & Palu & Merekatkan paku ke teriplek \\
\hline 6 & Amplas & Meratakan dan merapikan permukaan alas media \\
\hline 7 & Penggaris & Sebagai alat menentukan garis potong \\
\hline 8 & Lilin & Memanaskan plastik bening \\
\hline
\end{tabular}

Tabel 2: Bahan yang Digunakan untuk Membuat "Alga Maji"

\begin{tabular}{|c|l|l|}
\hline No & \multicolumn{1}{|c|}{ Bahan } & \multicolumn{1}{c|}{ Kegunaan } \\
\hline 1 & Triplek & Dasar media \\
\hline 2 & Papan ukuran kecil & Dasar media \\
\hline 3 & Kotak bekas & Sebagai miniatur ka'bah \\
\hline 4 & Paku kecil & Merekatkan papan pada triplek \\
\hline 5 & Lem Aibon & Merekatkan bahan-bahan miniatur haji \\
\hline 6 & Lem glukol & Merekatkan kertas \\
\hline 7 & Kuas cat & Mengecat dan mewarnai media "Alga Maji" \\
\hline 8 & Kertas amplop bekas & Sebagai miniatur bukit safa dan marwah \\
\hline 9 & Isolatif & Merekatkan miniature ke papan media \\
\hline 10 & Spidol & Menulis keterangan media \\
\hline 11 & Kardus bekas & Sebagai miniatur masjidil haram \\
\hline 12 & Kayu ukuran kecil & Sebagai miniatur tempat melontar jumrah di mina \\
\hline 13 & Cat kayu cap kuda terbang & Mewarnai riplek dan kayu alas media "Alga Maji" \\
\hline
\end{tabular}

Berdasarkan desain yang telah dibuat sebelumnya, mulailah tahapan pembuatan bagian-bagian "Alga Maji", yang nantinya akan dirancang dan disusun menjadi suatu media pembelajaran. Kelebihan dari media pembelajaran "Alga Maji", yaitu dapat diurai kembali bagianbagian utamanya setelah disatukan menjadi "Alga Maji".

\section{Aplikasi Praktis dalam Pembelajaran}

Setelah melalui beberapa proses pembuatan dan pengembangan, revisi dan uji coba terbatas, serta diseminasi (diuraikan pada bagian lain), media pembelajaran "Alga Maji" akhirnya siap diperkenalkan dan digunakan dalam pembelajaran di kelas. Seluruh siswa kelas IX A SMP Negeri 4 Gantung sebanyak 27 siswa, mengikuti pembelajaran pada hari Rabu tanggal 19 September 2018. Pada pembelajaran tersebut, penulis minta bantuan satu orang guru sebagai observer untuk melakukan penilaian terhadap proses pembelajaran. Waktu yang digunakan, yaitu 
selama 4 jam pelajaran, sesuai dengan alokasi waktu yang tersedia bagi materi pelajaran haji dan umrah. Langkah-langkah pembelajaran materi haji dan umrah menggunakan media "Alga Maji” dilakukan sebagai berikut.

1. Guru membuka kegiatan pembelajaran dengan kegiatan memberi salam, berdoa, membimbing siswa membaca surat pendek alqur'an, absensi kehadiran kelas dan pengkondisian kelas.

2. Guru memberikan apersepsi dengan cara memberikan pernyataan dan pertanyaan tentang haji dan umrah.

3. Memberikan kesempatan kepada siswa untuk menyampaikan jawaban dan pendapatnya tentang haji dan umrah.

4. Guru menyampaikan tujuan pembelajaran serta menjelaskan hal-hal yang akan dilakukan pada proses pembelajaran.

5. Guru menayangkan video ritual haji di layar proyektor.

6. Guru meminta masing-masing siswa mengerjakan lembar tes (pretest) berisi 10 soal pilihan ganda yang berkaitan video haji dan umrah.

7. Setelah seluruh siswa selesai mengerjakan lembar tes, guru kemudian memperkenalkan media pembelajaran "Alga Maji", mulai dari tampilan serta penjelasan tentang manfaat "Alga Maji" dalam pembelajaran materi haji dan umrah.

8. Guru meminta siswa membaca penjelasan tentang materi haji pada buku PAI yang telah disediakan.

9. Guru meminta seluruh siswa berkumpul, membentuk satu kelompok dengan cara melingkari meja yang terdapat "Alga Maji". Dalam kelompok besar tersebut, dibuat lagi empat kelompok kecil yang beranggotakan masing-masing 4 siswa.

10. Guru menjelaskan "Alga Maji" dan memposisikan kegiatan ibadah haji dan umrah untuk melakukan simulasi pelaksanaan haji.

11. Saat siswa melakukan pengamatan dan eksplorasi "Alga Maji", guru membantu memberikan penjelasan tentang proses pelaksanaan rukun dan syarat haji. 


\section{Heriyanto}

12. Setelah proses pelaksanaan haji telah disimulasikan, siswa setiap kelompok diminta mensimulasikan kegiatan haji melalui manasik haji di depan kelas.

13. Setiap kelompok siswa melakukan pengamatan dan penilaian terhadap masing-masing kelompok kelas yang mensimulasikan manasik haji menentukan kesalahan atau ketepatan dari apa yang mereka amati.

14. Setelah seluruh kelompok siswa selesai mempresentasikan hasil pengamatannya, dan masing-masing kelompok telah memberikan tanggapan, guru kemudian memberikan penjelasan utuh dan konfirmasi terhadap hasil yang dicapai siswa.

15. Sebelum memberikan kesimpulan pembelajaran sebagai bagian penutup pembelajaran, siswa diminta mengerjakan kembali lembar tes (post test) berisi 10 soal pilihan ganda yang berkaitan dengan haji dan umrah.

Selama proses pembelajaran dilaksanakan, observer melakukan penilaian terhadap pembelajaran termasuk aktivitas dan minat siswa mengikuti pembelajaran. Hasil penilaian disampaikan pada bagian berikutnya. Hasil observasi penulis menunjukkan "Alga Maji" sangat menarik perhatian siswa sehingga seluruh siswa fokus mengikuti pembelajaran.

\section{Analisis Data Hasil Aplikasi Praktis}

Efektivitas keberhasilan pembelajaran Pendidikan Agama Islam pada materi Haji dan Umrah dengan menggunakan media "Alga Maji" dapat diketahui dari data yang diperoleh selama proses pembelajaran. Adapun data yang diperoleh dari penggunaan media "Alga Maji" sebagai berikut.

\section{1) Hasil Pengamatan Selama Proses Pembelajaran.}

Selama pembelajaran PAI menggunakan media "Alga Maji”, siswa terlihat sangat antusias mengikuti pembelajaran. Hal ini dapat diketahui dari beberapa siswa yang aktif mencoba media "Alga Maji" meskipun jam pelajaran telah selesai. Dengan demikian, dapat dikatakan bahwa media 
"Alga Maji" dapat menumbuhkan perasaan senang dan meningkatkan rasa ingin tahu siswa kelas IX A SMP Negeri 4 Gantung.

2) Respon Siswa terhadap Penggunaan Media "Alga Maji" selama Pembelajaran.

Selain menggunakan lembar pengamatan, untuk mengetahui efektivitas dan keberhasilan pembelajaran yang dilakukan juga digunakan angket. Angket tersebut digunakan untuk mengetahui respon siswa ketika menggunakan media "Alga Maji" dalam pembelajaran Pendidikan Agama Islam. Berdasarkan data isian angket siswa, di bawah ini disajikan tabel untuk mengetahui respon peserta didik belajar dengan menggunakan media "Alga Maji". Mereka diminta mengisi angket tertutup mengenai pengalaman mereka saat menggunakan media ini dalam pembelajaran Pendidikan Agama Islam (PAI) materi haji dan umroh.

Tabel 3: Persentase Pengisian Angket Peserta Didik Setelah Belajar dengan Menggunakan Media "Alga Maji"

\begin{tabular}{|c|l|c|c|}
\hline \multirow{2}{*}{ No } & \multicolumn{1}{|c|}{ Pertanyaan } & \multicolumn{2}{|c|}{ Pilihan } \\
\cline { 3 - 4 } & \multicolumn{1}{|c|}{$\begin{array}{c}\text { Sangat } \\
\text { Setuju }\end{array}$} & Setuju \\
\hline 1 & $\begin{array}{l}\text { Apakah belajar dengan menggunakan media "Alga Maji" } \\
\text { membuat kamu senang dan bersemangat? }\end{array}$ & $96,7 \%$ & $3,3 \%$ \\
\hline 2 & $\begin{array}{l}\text { Apakah belajar dengan menggunakan media "Alga Maji" } \\
\text { membuat kamu berani dan percaya diri tampil kedepan? }\end{array}$ & $93,3 \%$ & $6.7 \%$ \\
\hline 3 & $\begin{array}{l}\text { Apakah belajar dengan menggunakan media "Alga Maji" } \\
\text { membuat kamu bertanggung jawab dan amanah? }\end{array}$ & $90 \%$ & $10 \%$ \\
\hline 4 & Apakah penggunaan media "Alga Maji" mudah di presentasikan? & $96,7 \%$ & $3,3 \%$ \\
\hline 5 & $\begin{array}{l}\text { Apakah kamu ingin belajar kembali dengan menggunakan media } \\
\text { "Alga Maji"? }\end{array}$ & $93,3 \%$ & $6,7 \%$ \\
\hline
\end{tabular}

Pada proses pembelajaran dengan menggunakan media "Alga Maji" peserta didik sangat aktif, senang, dan bersemangat dalam belajar. Seluruh peserta didik tampak mengikuti pembelajaran dengan riang dan gembira. Hal ini ditujukkan melalui hasil angket yang menunjukkan nilai 96,7\% peserta didik sangat setuju belajar dengan menggunakan media "Alga Maji" membuat mereka senang dan bersemangat dalam belajar. Peserta didik menunjukkan sikap berani dan percaya diri ketika tampil ke depan untuk menjawab pertanyaan. Hal ini disebabkan karena mereka rileks dan menikamti proses tersebut. Hal ini ditunjukkan melalui angket 


\section{Heriyanto}

yang menunjukkan nilai 93,3\% peserta didik berani dan percaya diri ketika tampil ke depan. Keberanian dan kepercayaan diri itu terbangun melalui pembelajaran yang menggunakan media "Alga Maji".

Melalui belajar dengan menggunakan "Alga Maji" peserta didik menunjukkan sikap bertanggung jawab dan amanah. Sikap tanggung jawab dan amanah ini didapatkan ketika proses dimana peserta didik mendapatkan kesempatan yang sama untuk menjawab pertanyaan yang didapatkan. Belajar dengan menggunakan media "Alga Maji” sangat mudah diaplikasikan pada pebelajaran. Guru cukup sekali memberikan penjelasan diawal selanjutnya peserta didik yang berperan aktif pada proses pembelajaran. Hal ini berdasarkan juga hasil angket yang menunjukkan 96,7\% peserta didik menyatakan pembelajaran menggunakan media "Alga Maji" sangat mudah diterapkan.

\section{3) Hasil Belajar Siswa}

Tidak dapat dipungkiri sebagai salah satu faktor penentu keberhasilan penggunaan sebuah media pembelajaran adalah terjadi peningkatan hasil belajar siswa. oleh karena itu, untuk mengetahui sejauh mana keberhasilan penggunaan media Alat Peraga Manasik Haji “Alga Maji" dilakukan 2X tes yaitu sebelum dan sesudah. Tujuannya adalah untuk melihat apakah ada peningkatan hasil belajar siswa setelah menggunakan media "Alga Maji" dan tuntas belajar pada materi Haji dan Umrah. Siswa dikatakan tuntas belajar jika mendapatkan nilai di atas KKM yang telah ditetapkan yaitu 75 Adapun hasil belajar yang diperoleh siswa adalah sebagai berikut.

Tabel 4: Hasil Tes Setelah Implementasi Menggunakan Media "Alga Maji"

\begin{tabular}{|c|l|c|c|}
\hline No & \multicolumn{1}{|c|}{ Nama Siswa } & Nilai & Keterangan \\
\hline 1 & Abdul Aziz & 77 & Tuntas \\
\hline 2 & Amad Halim & 76 & Tuntas \\
\hline 3 & Asiah Putri Amisani & 75 & Tuntas \\
\hline 4 & Akbar Ramadhan & 76 & Tuntas \\
\hline 5 & Ahmad Wari & 78 & Tuntas \\
\hline 6 & Alifian FS & 96 & Tuntas \\
\hline 7 & Biyan & 95 & Tuntas \\
\hline 8 & Cindy R & 75 & Tuntas \\
\hline
\end{tabular}




\begin{tabular}{|c|l|c|c|}
\hline 9 & Destiana & 83 & Tuntas \\
\hline 10 & Diana & 84 & Tuntas \\
\hline 11 & Dina Piroza & 85 & Tuntas \\
\hline 12 & Elen MI & 77 & Tuntas \\
\hline 13 & Firanti & 94 & Tuntas \\
\hline 14 & Iyan YB & 83 & Tuntas \\
\hline 15 & Jesica S & 92 & Tuntas \\
\hline 16 & Muhammad Alfi Syahrin & 75 & Tuntas \\
\hline 17 & Napiola & 75 & Tuntas \\
\hline 18 & Neti Ramadani & 95 & Tuntas \\
\hline 19 & Neti & 86 & Tuntas \\
\hline 20 & Reni Resnita & 94 & Tuntas \\
\hline 21 & Rindi Dilpani & 78 & Tuntas \\
\hline 22 & Ramadhan & 79 & Tuntas \\
\hline 23 & Sukawati & 75 & Tuntas \\
\hline 24 & Selimi & 98 & Tuntas \\
\hline 25 & Tanjung Putra & 76 & Tuntas \\
\hline 26 & Wingky Agusti & 75 & Tuntas \\
\hline 27 & Yesi & & \\
\hline
\end{tabular}

\section{Analisis Data Hasil Aplikasi Praktis Inovasi Pembelajaran}

Sesuai dengan kegiatan pembelajaran yang dilakukan, diperoleh beberapa data aplikasi praktis pembelajaran dengan menggunakan media "Alga Maji". Data tersebut kemudian diolah untuk mengetahui apakah penggunaan media "Alga Maji" mempengaruhi motivasi dan hasil belajar siswa kelas IX A SMP Negeri 4 Gantung Kabupaten Belitung Timur.

\section{1) Hasil Pengamatan Selama Proses Pembelajaran}

Berdasarkan hasil pengematan selama proses pembelajaran, diperoleh beberapa kejadian yang menunjukkan bahwa media "Alga Maji" mampu menjadikan siswa aktif dalam pembelajaran. Hal ini dapat diketahui dari beberapa siswa yang asyik menggunakan media meskipun waktu pembelajaran sudah berakhir.

Selama proses pembelajaran PAI dengan menggunakan media "Alga Maji" siswa mampu bekerja sama dengan anggota kelompoknya untuk menentukan kegiatan ritual haji dan umrah. Kemudian, dengan penuh semangat siswa melakukan pembuktian atas prediksi yang diperolehnya, baik menggunakan media "Alga Maji" dan Video Ritual haji. Dengan demikian, dapat dikatakan bahwa media "Alga Maji" dapat 
meningkatkan aktivitas siswa dalam pembelajaran PAI materi Haji dan Umrah.

\section{2) Hasil Belajar Siswa}

Data hasil belajar siswa diperoleh dari hasil evaluasi terhadap soal yang diberikan oleh guru. Untuk mengetahui apakah ada peningkatan hasil belajar siswa menggunakan media "Alga Maji", dilakukan $2 X$ tes. Pertama dilakukan sebelum menggunakan media dan tes kedua dilakukan menggunakan media.

Berdasarkan hasil perolehan nilai peserta didik dari post test yang dilaksanakan setelah dilaksanakan pembelajaran menggunakan media "Alga Maji" menunjukkan hasil sebagai berikut:

Tabel 5: Hasil Belajar Peserta Didik Setelah Diterapkan Inovasi

\begin{tabular}{|c|c|l|c|c|c|}
\hline No & Rentang Nilai & Kategori & Jumlah Siswa & Persetase & Keterangan \\
\hline 1 & $91-100$ & Sangat Baik & 7 & $25 \%$ & Tuntas \\
\hline 2 & $81-90$ & Baik & 6 & $25 \%$ & Tuntas \\
\hline 3 & $70-80$ & Cukup & 14 & $50 \%$ & Tuntas \\
\hline 4 & $\leq 70$ & Kurang & 0 & $0 \%$ & Tdk Tuntas \\
\hline \multicolumn{2}{|c|}{ Jumlah } & 27 & $100 \%$ & \\
\hline
\end{tabular}

Hasil belajar pada tabel 5 tersebut menjelaskan dari 27 orang peserta didik terdapat 7 orang ( $25 \%$ ) yang mendapatkan kategori sangat baik dengan rentang nilai 91-100, terdapat 6 orang (25\%) yang mendapatkan kategori baik dengan rentang nilai 81-90, terdapat 15 orang (50 \%) yang mendapatkan kategori cukup dengan rentang nialai 70-80. Hall ini menunjukkan bahwa seluruh peserta didik yang berjumlah 27 orang tuntas dalam pembelajaran. Oleh sebab itu, dapat disimpulkan bahwa pembelajaran Pendidikan Agama Islam (PAI) materi haji dan umrah dengan menggunakan media "Alga Maji" dapat meningkatkan ketuntasan belajar peserta didik khususnya materi haji dan umrah. Hal ini dapat dibuktikan dari jumlah dan persentase peserta didik yang mencapai ketuntasan belajar 100 \%. Pembelajaran Pendidikan Agama Islam pada kelas IX A SMP Negeri 4 Gantung materi Haji dan Umrah dengan menggunakan media "Alga Maji" menunjukkan proses pembelajaran 
yang membuat peserta didik termotivasi dan bersemangat serta meningkatkan hasil belajar peserta didik.

\section{Penutup}

Pembelajaran PAI materi haji dan umrah dengan menggunakan media "Alga Maji" dapat mewujudkan pembelajaran abad 21 dan era revolusi industri 4.0 yaitu: berfikir kritis dalam menjawab pertanyaan, berkolaborasi dalam menyelesaikan masalah, berkomunikasi aktif dan juga menunjukkan kreativitas dalam pembelajaran.

Penggunaan media "Alga Maji" dalam pembelajaran Pendidikan Agama Islam materi Haji dan Umrah dapat meningkatkan hasil belajar peserta didik. Hal ini didukung proses pembelajaran yang menyenangkan dan memotivasi peserta didik serta memudahkan untuk menguasai materi dengan metode pembelajaran Audio Visual.

\section{Ucapan Terimakasih}

Terima kasih saya sampaikan kepada Bapak Kepala Sekolah dan teman-teman guru di SMP Negeri 4, Gantung, Belitung Timur, Bangka Belitung yang telah memberikan bantuan, baik waktu, tenaga, maupun pemikiran sehingga penelitian pengembangan dan penulisan artikel ini dapat diselesaikan dengan baik. Semoga Tuhan Yang Maha Esa memberikan balasan yang setimpal. Aamiin.

\section{Daftar Referensi}

Arsyad, Azhar.2007. Media Pembelajaran. Jakarta: Raja Grafindo Persada

Dahar, Ratna Wilis. 2011. Teori-Teori Belajar dan Pembelajaran. Bandung: Erlangga

Daryanto. 2012. Media Pembelajaran. Bandung: PT.Satu Nusa

Djamarah, Syaiful Bahri,dkk.2010. Strategi Belajar Mengajar. Jakarta: Rineka Cipta

Sudjana, Nana.2009. Penilaian Hasil Proses Belajar Mengajar. Bandung: Rosda Karya 